\title{
Use of Agroecological Techniques by Smallholder Farmers to Improve Sorghum Productivity in Burkina
}

\section{Faso}

Zomboudré Georges ${ }^{1}$, Youma Issaka Abdoulaye ${ }^{2}$, Batta Fatou ${ }^{3}$, Kaboré Roger ${ }^{4}$, Bourgou Tsuamba ${ }^{5}$ and Gubbels Peter $^{3}$

1. Department of Natural Resource Management, Institute for Environment and Agricultural Research (INERA), 04 BP 8645

Ouagadougou 04, Burkina Faso

2. Institute for Environment Science and Rural Development (ISEDR), University of Dédougou, BP 176 Dédougou, Burkina Faso

3. Groundswell International, PO Box 2257 Asheville, NC 28802, USA

4. Association Minim Song Panga (AMSP), BP 268 Kaya, Burkina Faso

5. Association Nourrir Sans Détruire (ANSD), 09 BP 1670 Ouagadougou 09, Burkina Faso

\begin{abstract}
The prevailing farming system in Burkina Faso is smallholder agriculture based on cereal production, especially sorghum (Sorghum bicolor (L.) Moench) which form the staple diet for the population. Production is constantly challenged by climate hazards, striga (Striga hermonthica (Del.) Benth.) infestation, inefficient farming practices and declining soil fertility. To address these concerns, one study on several agroecological techniques was conducted from 2013 to 2015 in a participative manner with more than 150 male and female farmers from four communities. Each farmer was asked to test out two or three agroecological techniques of his choice and to measure these new techniques against their usual farming practices. These techniques combined the use of organic fertilizer ( $5 \mathrm{t} / \mathrm{ha}$ ) and/or mineral fertilizer ( $2 \mathrm{~g} / \mathrm{seed}$ hole) with the systems of crop rotation and mixed cropping, in addition to the improved zaï technique and the half-moon method. Plant material was composed of local landraces and improved varieties of sorghum, sesame and cowpea. On-farm application of agroecological techniques resulted in significantly increased sorghum production in all four communities. The rates of increase for grain yield were $8 \%$ for the half-moon fields and more than $130 \%$ for the rotation systems when compared to the farmers' usual practices. More limited results were achieved with the chemical components of the soil after two years of experimentation. Only the soil's organic matter showed improvement over the first year. This study shows that crop rotation, mixed cropping and the improved zaï technique in combination with compost and improved drought-resistant varieties constitute agroecological strategies favorable to the intensification and diversification of farming systems in the studied locations. The farmers were above all impressed by the on-site management of compost by means of the zaï technique which enabled large-scale fertilization of fields.
\end{abstract}

Key words: Agroecological techniques, sorghum, yield, compost, mineral fertilizer, crop rotation, mixed cropping, zaï.

\section{Introduction}

Burkina Faso is a tropical country located in the West-African region and covers an area of 274,200 $\mathrm{km}^{2}$ with a total population of 16 million [1]. Agriculture and animal husbandry are essential elements of the national economy, employing $80 \%$ of

Corresponding author: Zomboudré Georges, Ph.D., research fields: agroecology, soil and water management. the population and accounting for $40 \%$ of GDP [2]. The prevailing farming system is smallholder agriculture based on cereal production, especially sorghum, pearl millet and maize that form the staple diet for the population. The tree crops occupy almost 2.9 million hectares of land and sorghum covers $44 \%$ of these areas with an average production of 1.5 million tons [3]. This production is $90 \%$ own consumption. 
Sorghum cultivation is possible in areas where rainfall is greater than $500 \mathrm{~mm}$ [4]. Red sorghum as white sorghum is more grown in pure and in association with legumes. Cultural practices such as crop association and crop rotation are being adopted by farmers for their effectiveness against the sorghum weeds such as the "striga" but also for improving soil fertility [5]. The application of organic and mineral fertilizer shows that the quantities used are quite disparate from one season to another and insufficient to meet crop needs [6, 7].

Spatial distribution of crop sequences revealed a permanence of continuous sorghum cropping or rotation sorghum millet. The continuing use of low external input farming practices by small scale farmers accentuates the imbalance of nutrients for crop needs and declining agricultural yields. In addition, the annual plowing fields required by the rotation of cereals followed by cereals, as well as the export of crop residues for domestic purposes, inevitably leads to a gradual degradation of soil structure, erosion and declining of soil organic matter $[8,9]$. To improve the productivity of agricultural areas prone to this risk of declining soil fertility and to ensure stability of production, small scale farmers have been encouraged to adopt the use of various improved soil fertility techniques (i.e., micro-dose application of chemical fertilizer, manure from animal corrals, compost, use of improved varieties), techniques of water and soil conservation (contour bunds, zai, half-moons, vegetative strips, minimum tillage) and agroforestry practices. These recommendations were derived from research in which the key parameters were studied in isolation. The combined effects of these production factors known as agroecological practices have not been sufficiently addressed [10]. Organic fertilization by half-moon and zaï techniques has been used to restore the fertility of the soil bare at the end of 3-5 years [11, 12]. Studies on the stone barriers, the grass strips, the improved fallows, cereals rotation or association with legumes highlighted the good water conservation and the sustainable management of soil fertility [13-15]. It is therefore necessary to assess these interactions and provide recommendations on how to gradually enable small scale farmers in the buffer zone to make the transition to more intensive cropping systems that take into account ecological, economic and social dimensions. One objective of this study was to evaluate, in a participatory manner, the impact of these agroecological techniques on soils and crops. Another was to help local communities to understand these techniques and to adapt them, as they saw fit, in their fields with the aim of sustainably managing their lands and improving their wellbeing by increased production and income from these techniques.

\section{Materials and Methods}

The study on the impact of agroecological techniques was conducted from 2013 to 2015 in a participative manner with more than 150 male and female farmers from the communities of Korsimoro, Andemtenga, Bilanga and Gayérie. The four communities are located in the agroecological buffer zone I and II in North Eastern Burkina Faso that receives a rainfall of about $700 \mathrm{~mm}$ on average per year (Fig. 1). This buffer zone is considered an area of high environmental risk where food insecurity and natural resource degradation mutually reinforce one another.

Each farmer was asked to test out two or three agroecological techniques of his choice and to measure these new techniques against their usual farming practices. These techniques combined the use of organic fertilizer ( $5 \mathrm{t} / \mathrm{ha}$ ) and/or mineral fertilizer (2 g/seed hole) with the systems of crop rotation and mixed cropping, in addition to the improved zaï technique and the half-moon method (Table 1). Zaï and half-moon pits are water collection techniques, implemented on bare and crusted soils. Additionally to the water harvest function, benefits of localized tillage occur and animal manure or other organic and/or 


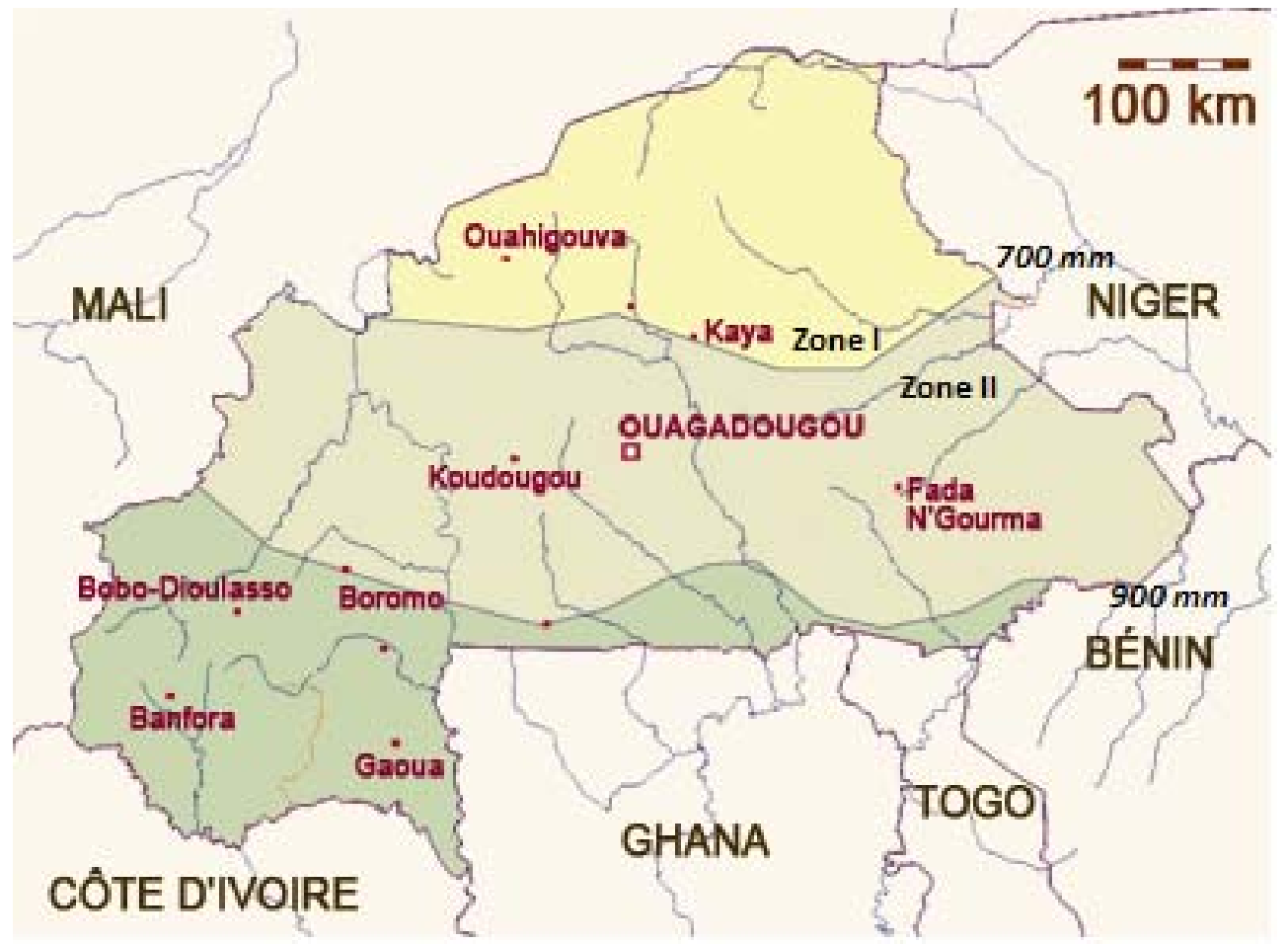

Fig. 1 Map of Burkina Faso with project buffer zone (zone I and zone II) [18].

Table 1 Agroecological technologies applied on sorghum.

\begin{tabular}{ll}
\hline Agroecological technologies & Description \\
\hline Rotation sorghum-cowpea & Crop rotation: sorghum-cowpea/sesame + micro-dosing of mineral fertilizer + organic material \\
& $(5 \mathrm{t} / \mathrm{ha})$ \\
Intercropping sorghum-cowpea & Intercropping sorghum-cowpea/sesame (in band of four lines $)+$ micro-dosing of mineral \\
Zaï & fertilizer \\
Half moons & Zai + organic material ( $300 \mathrm{~g} / \mathrm{hole})+$ micro dosing of mineral fertilizer \\
Control & Half-moons + organic material $(30 \mathrm{~kg} / \mathrm{hole})+$ micro dosing of mineral fertilizer \\
\hline
\end{tabular}

inorganic material can be brought in the basin to optimize crop growth. While the zaï technique uses smaller pits of $30 \mathrm{~cm}$, half-moon pits consist of semi-circular basins that are several meters wide. Micro-dosing of mineral fertilizer is a method that consists of applying small amounts of fertilizer directly into the planting hole. It is therefore supposed to reduce the required total amount of fertilizer, thereby being more affordable to small-scale farmers. Plant material was composed of local landraces and improved varieties of sorghum, sesame and cowpea. These improved varieties are already being promoted in the project area because of their performance such as tolerance to heavy rains, the parasitic weed "striga” and drought, early maturity and high production potential. The organic carbon of the composite soil samples collected in the $0-20 \mathrm{~cm}$ horizon in each plot of agroecological technologies has been analyzed at the laboratory by the Walkley and Black method [16]. The degree of "striga" infestation was done from a count of the number of plants emerged in the plots of $0.25 \mathrm{~m}^{2}(0.5 \mathrm{~m} \times 0.5 \mathrm{~m})$ shortly before the sorghum harvest. Collected data were subjected to analysis of variance (ANOVA) using Minitab (V. 14) statistical software for Windows (Minitab Inc.). Means that showed differences at $p<0.05$ and averages were compared using Newman Keuls tests [17]. Data of emerged "striga" were analyzed after logarithmic 
transformation $[\log (x+1)]$.

\section{Results and Discussion}

\subsection{Effects of Agroecological Technologies on} Sorghum Productivity

On-farm application of agroecological technologies resulted in significantly increased sorghum production in all four communities. The rates of increase for grain yield were $8 \%$ for the half-moon fields and more than $130 \%$ for the rotation systems when compared to the farmers' usual practices (Fig. 2). Statistical analysis indicated however that yields for the half-moons fields were not significantly higher than the farmers' usual practices.

The best yields under sorghum-cowpea rotation can be explained by the addition of organic manure and by the residual nitrogen of cowpea. The residual effects of legumes crops occur at root nodules and residues such as leaves and stems that constitute a nitrogen stock for the next cropping season [19, 20]. Eaglesham et al. [21] found that the residual effect of cowpea was equivalent to $36 \mathrm{~kg} / \mathrm{ha}$ of nitrogen added to the soil.

Sorghum grain yields obtained under sorghum-cowpea rotation $(1,565 \mathrm{~kg} / \mathrm{ha})$ was higher than those observed by Bado [20] who found 733 $\mathrm{kg} / \mathrm{ha}$ in kouaré under similar climatic conditions. However, Traoré [4] obtained an average yield of 1,765 kg/ha sorghum-cowpea rotation in Farako-bâ under a much humid climate. The highest yields under intercropping practice could be partly explained by the residual effect of cowpea or sesame after the permutation of the bands.

Zaï and half-moons practices have improved crops yields on poor soils allowed previously unexploited and abandoned. Indeed, Sawadogo et al. [21] obtained $719 \mathrm{~kg} / \mathrm{ha}$ under zaï practice and $0 \mathrm{~kg} / \mathrm{ha}$ under the absolute control; similarly, Zougmoré and Zida [22] obtained $875 \mathrm{~kg} / \mathrm{ha}$ on half-moons with compost applied and $42 \mathrm{~kg} / \mathrm{ha}$ on half-moons without fertilization. These two examples better illustrate the role of organic and mineral manure in zaï and in half-moons compared to the control.

3.2 Agroecological Technologies Impacts on Soil Chemical Characteristics

Generally, zaï has several advantages and has been unanimously appreciated by farmers for various reasons. First of all, it saves compost, because of its localized application which reduces the losses by the runoff during the rainy season. Then, making the compost during the dry season (free period of farmers)

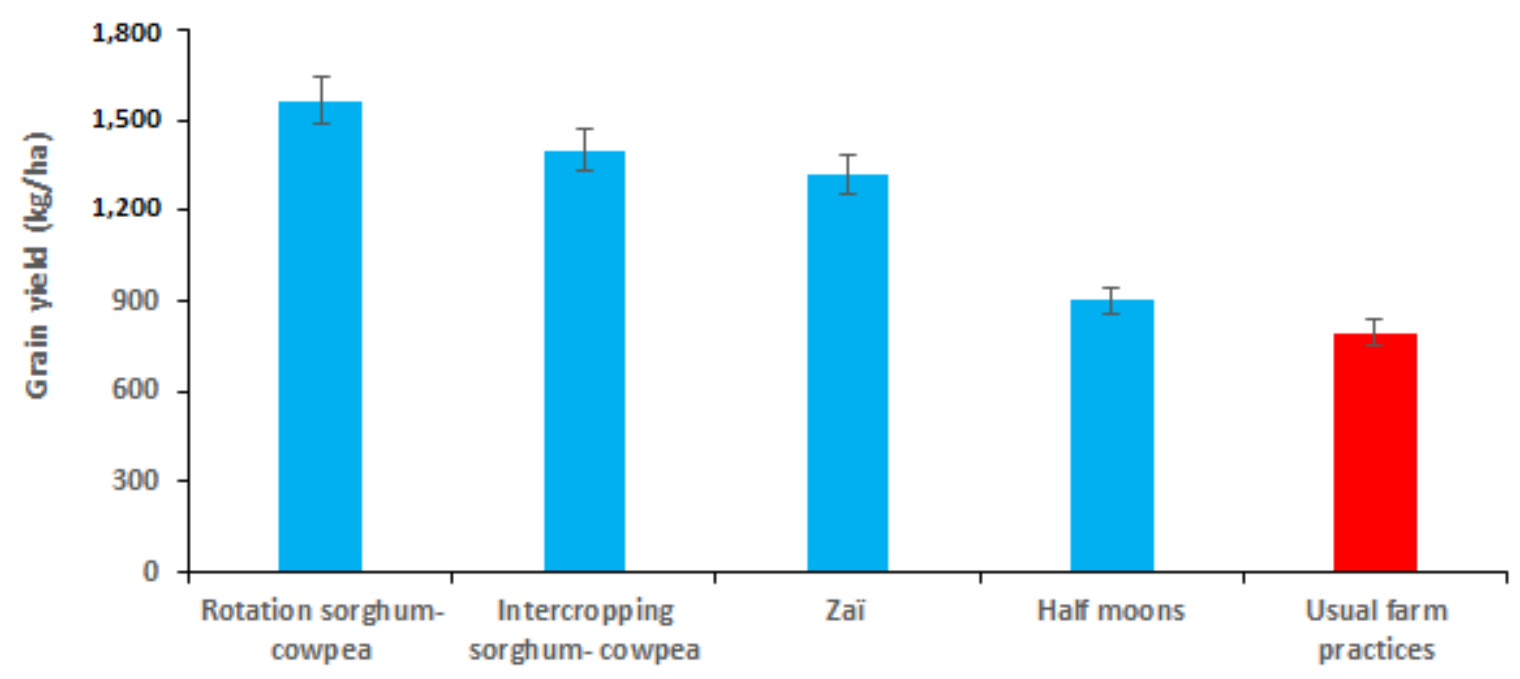

Fig. 2 Sorghum yield under agroecological techniques compared to farmer practices in the four communities. 
is attractive for farmers. Lastly, zaï is appreciated for its good performance. The average yield under zaï and half-moons is higher than the average sorghum yield in the buffer zone which was $811 \mathrm{~kg} / \mathrm{ha}$ in 2014 [23]. This difference in yield could be due to the optimal use of organic and mineral manure, but also to the conservation of moisture by the zai pits during the dry spell periods [24]. Sorghum yields obtained under half-moons practice was also similar to those found by Zougmoré et al. [12] in Pougyango in North Western Burkina Faso. The half-moons due to the areas occupied by the impluviums have low yields per hectare. The chemical characteristics of the soil showed a mixed evolution after two years of experimentation. Only the organic matter content was improved after two years of experimentation (Fig. 3).

Statistical analysis did not show any significant difference between agroecological technologies for phosphorus, potassium and water $\mathrm{pH}$ (Table 2). In terms of organic matter and total nitrogen, their contents under half-moons practice was statistically higher $(p=0.05)$ than those of sorghum-cowpea intercropping and improved zaï.

The higher organic matter under half-moons practice compared to zaï, could be explained by the fact that the organic manure was brought into the half-moons every year. Zaï pits locations generally vary from season to season [24]. The absence of significant differences between the technologies for phosphorus, potassium and water $\mathrm{pH}$ could be due to the fact that both organic and inorganic inputs were similar for all the technologies and to the rainfall that affect the availability of the nutrients [24-26].

\subsection{Impact of Agroecological Technologies on Striga Hermonthica Infestation}

The density of the $S$. hermonthica infestation ranges from 0.8 plants $/ \mathrm{m}^{2}$ to 157 plants $/ \mathrm{m}^{2}$ with average infestations under the technologies ranging from 9.03 plants $/ \mathrm{m}^{2}$ under improved zaï to 26.46 plants $/ \mathrm{m}^{2}$ under

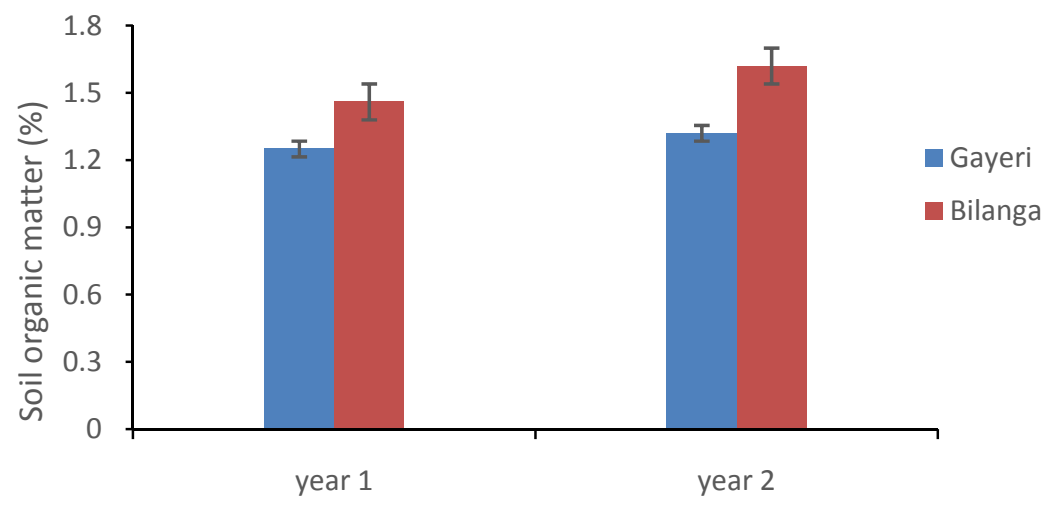

Fig. 3 Change in soil organic matter content over years 1 \& 2 of trials in the communes of Gayéri and Bilanga.

Table 2 Soil chemical characteristics according to agroecological technologies*.

\begin{tabular}{lllllll}
\hline Agroecological technologies & Organic matter (\%) & Nitrogen (\%) & $\mathrm{C} / \mathrm{N}$ & Phosphorus (g/kg) & Potassium (\%) & $\mathrm{pH}(\mathrm{in}$ water) \\
\hline Sorghum-cowpea rotation & $1.34 \mathrm{ab}$ & $0.047 \mathrm{ab}$ & $16.61 \mathrm{a}$ & $0.33 \mathrm{a}$ & $0.13 \mathrm{a}$ & $5.99 \mathrm{a}$ \\
Intercropping sorghum-cowpea & $1.10 \mathrm{a}$ & $0.042 \mathrm{ab}$ & $15.29 \mathrm{a}$ & $0.31 \mathrm{a}$ & $0.13 \mathrm{a}$ & $5.89 \mathrm{a}$ \\
Zaï & $1.15 \mathrm{a}$ & $0.037 \mathrm{a}$ & $17.97 \mathrm{a}$ & $0.31 \mathrm{a}$ & $0.12 \mathrm{a}$ & $6.07 \mathrm{a}$ \\
Half moon & $1.61 \mathrm{~b}$ & $0.058 \mathrm{~b}$ & $16.95 \mathrm{a}$ & $0.37 \mathrm{a}$ & $0.14 \mathrm{a}$ & $6.21 \mathrm{a}$ \\
Means & 1.29 & 0.049 & 16.7 & 0.33 & 0.13 & 6.04 \\
Standard deviation & 0.46 & 0.19 & 3.34 & 0.12 & 0.54 & 0.6 \\
CV \% & 35.66 & 38.78 & 20 & 36.36 & 42.52 & 9.93 \\
\hline
\end{tabular}

*Data in the same column with different letters are significantly different at $p<0.05$.

$\mathrm{CV}$ : coefficient of variance. 
Table 3 Density of Striga hermonthica infestations (plants $/ \mathrm{m}^{2}$ ) by farmer's agroecological technologies*.

\begin{tabular}{lll}
\hline \multirow{2}{*}{ Agroecological technologies } & \multicolumn{1}{c}{ Infestation density (plants $\left./ \mathrm{m}^{2}\right)$} \\
\cline { 2 - 3 } & Gross mean & Transformed mean \\
\hline Rotation sorghum-cowpea & $10.26 \mathrm{~b}$ & $0.74 \mathrm{~b}$ \\
Intercropping sorghum-cowpea & $15.21 \mathrm{ab}$ & $0.86 \mathrm{ab}$ \\
Improved zaï & $9.03 \mathrm{~b}$ & $0.68 \mathrm{~b}$ \\
Half-moon & $13.49 \mathrm{ab}$ & $0.74 \mathrm{ab}$ \\
Farmer’s practice & $26.46 \mathrm{a}$ & $1.04 \mathrm{a}$ \\
Mean & 14.89 & 0.81 \\
Standard deviation & 24.04 & 0.26 \\
CV \% & 160.43 & 31.44 \\
\hline
\end{tabular}

*Data in the same column with different letters are significantly different at $p<0.05$.

$\mathrm{CV}$ : coefficient of variance.

farmer's practice (Table 3). These results show that all technologies were infested without exception. Statistical analyzes reveal that the infestation under sorghum/cowpea rotation (10.26 plants $\left./ \mathrm{m}^{2}\right)$ and improved zaï practice $\left(9.03\right.$ plants $\left./ \mathrm{m}^{2}\right)$ were significantly different from that of the farmer's practice at a threshold of $5 \%$.

In the severely infested plots (31-157 plants $/ \mathrm{m}^{2}$ ) the average yield of sorghum was $930 \mathrm{~kg} / \mathrm{ha}$. The average production per hectare was $1,065 \mathrm{~kg}$ in slightly infested plots (0-5 plants $\left./ \mathrm{m}^{2}\right)$ and $985 \mathrm{~kg}$ in plots with medium infestation (6-30 plants $/ \mathrm{m}^{2}$ ). Yield reductions were respectively $7.42 \%$ and $12.69 \%$ in moderately infested plots and heavily infested soils plots. The sorghum-cowpea rotation is the second technology that has less $S$. hermonthica after improved zaï technology. In contrast, the density of 9.03 plants $/ \mathrm{m}^{2}$ of "striga" under improved zaï is not statistically different $(p=0.05)$ from that of the sorghum/cowpea intercropping (15.21 plants $/ \mathrm{m}^{2}$ ). Under improved zaï practice the effect of organic and mineral fertilizers appears to be more effective in reducing "striga" infestation due to the optimal use of organic matter. Organic manure application is done in the zaï pits, resulting in high organic matter content [12, 26]. Under sorghum-cowpea rotation, the suicide effect of cowpea and sesame germination as false host plants of $S$. hermonthica in the first year has contributed in decreasing "striga" seeds, thus contributing to a reduction in S. hermonthica infestations during the second year. This was the same case for sorghum/cowpea intercropping. Several studies have shown that the false hosts (cowpea and sesame) play a very positive role because these plants reduce substantially $S$. hermonthica seeds stock in the soil and thus, its infestation $[27,28]$.

\section{Conclusions}

This study shows that crop rotation, mixed cropping and the improved zaï technique in combination with compost and improved drought-resistant varieties constitute agroecological strategies favorable to the intensification and diversification of farming systems in the studied locations. The farmers were above all impressed by the on-site management of compost by means of the zaï technique which enabled large-scale fertilization of fields. Through innovative "scaling out" techniques, including farmer field schools and "farmer to farmer" training, the study enabled 6,832 farmers (over $40 \%$ women) in 80 villages across four communities to test and adapt various combinations of agroecological intensification (AEI) techniques. The farmers learned that the innovations such as assisted natural regeneration (ANR), contour rock bunds, zaï basins, composting, legume intensification in the context of rotation and intercropping and improved seeds best addressed their priority problems. In addition to these AEI techniques, many farmers also applied conventional micro-dosing of chemical fertilizer. 

Sorghum Productivity in Burkina Faso

\section{Acknowledgments}

This study was supported by the Collaborative Crop Research Program (CCRP) of the McKnight Foundation. It is the result of collaboration research between local and international researchers, development organizations and smallholder farmers from the communities of Korsimoro, Andemtenga, Bilanga and Gayérie. Thanks a lot the field technicians and the Municipal (Commune) authorities for their assistance during the experiment.

\section{References}

[1] INSD. 2010. "Yearbook of Agricultural Statistics." Technical document, Burkina Faso, 225. (in French)

[2] FAO, 2007. “The FAO Statistical Yearbooks 2005/2006.” http://www.fao.org/statistics/yearbook/vol_1_1/en.asp?pa ge=production. (in French)

[3] FAO. 2000. "FAO Production Yearbook." Collection FAO Statistical 163: 71-83. (in French)

[4] Traoré, M. 2012. “Impact of Agricultural Practices (Rotation, Fertilization and Tillage) on the Dynamics of the Microfauna and Macrofauna of the Soil under Sorghum and Cowpea Cultivation in the Western Center of Burkina Faso.” Ph.D. thesis, Polytechnic University of Bobo-Dioulasso, 137. (in French)

[5] Lawane, G., Sougnabe, S. P., Lendzemo, V., Gnokreo, F., Djimasbeye, N., and Ndoutamia, G. 2009. "Efficacy of Cereal and Cowpea Association for Grain Production and to Fight against Striga hermonthica (Del.).” Seiny-Boukar, L., and Boumard, P., eds, Garoua, Cameroun, 1-8. (in French)

[6] Vanlauwe, B., and Giller, K. E. 2006. "Popular Myths around Soil Fertility Management in Sub-Saharan Africa." Agriculture, Ecosystems and Environment 116: 34-46.

[7] Somda, B. B., Ouattara, B., Serme, I., Pouya, M. B., Lompo, F., Taonda, S. J. B., and Sedogo, P. M. 2017. "Determination of the Optimal Doses of Organo-Mineral Manure in Microdose in the Sudano-Sahelian Zone of Burkina Faso.” International Journal of Biology Chemistry Science 11 (2): 670-83. (in French)

[8] Lal, R. 1989. "Agroforestry Systems and Soil Surface Management of a Tropical Alfisol: I. Soil Moisture and Crop Yields.” Agroforestry Systems 8: 7-29.

[9] Ouattara, K., Ouattara, B., Assa, A., and Sédogo, P. M. 2006. "Long-Term Effect of Ploughing and Organic Matter Input on Soil Moisture Characteristics of a Ferric Lixisol in Burkina Faso.” Soil and Tillage Research 88: 217-24.
[10] David, C., Wezel, A., Bellon, S., Doré, T., and Malézieux, E. 2011. "Agroecology." In The Agricultural Words. History and Criticism, edited by Morlon, P., INRA-SAD. http://mots-agronomie.inra.fr/mots-agronomie.fr/index.ph p/Agroécologie. (in French)

[11] Vlaar, J. C. J. 1992. "Conservation Techniques of Water and Soil in the Countries of the Sahel.” CIEH Burkina Faso, Agricultural University of Wageningen, 99. (in French)

[12] Zougmoré, R., Zida, Z., and Kambou, N. F. 1999. "Rehabilitation of Degraded Soils: Roles of the Amendments in the Success of the Techniques of Half-Moon and Zaï in the Sahel.” Erosion Bulletin 19: 536-50. (in French)

[13] Roose, E., Kabore, V., and Guenat, C. 1995. “The Zaï, a Traditional African Technique of Rehabilitation of Degraded Lands of the Sudano-Sahelian Region (Burkina Faso).” In Can the Man Do What He Defeated? Edited by Pontanier, R., M’Hiri, A., Akrimi, N., Aronson, J., and Le Floc'h, E. John Libbey Eurotext, Paris, 249-65. (in French)

[14] Kayentao, M. 2007. "Management of Striga in Mali." In Progress on Farmers Training on Parasitic Weed Management, edited by Ricardo Labrada. FAO, Rome; 111-8.

[15] Bambara, D., Bilgo, A., Traoré, H., Lompo, F., Thiombiano, A., and Hien, V. 2012. "Assessment of the Effects of Zaï and Bunds Arrangement for Long-Term Grain Productivity in the North of Burkina Faso." Bulletin of Agricultural Research of Benin (BRAB) 71: 13-25. (in French)

[16] Walkley, A., and Black, I. A. 1934. "An Examination Method of the Detjareff and a Proposed Modification of the Chromic Acid Titration Method.” Soil Science 37: 29-38.

[17] Keuls, M., 1952. "The Use of the Studentized Range in Connection with an Analysis of Variance.” Euphytica 1: 112-22.

[18] Hua Ngoc, N. 2009. "Gold Mine in Burkina Faso." https://www.icem-pedagogie-freinet.org/node/8105. (in French)

[19] Chalck, P. M. 1998. "Dynamics of Biologically Fixed N in Legume-Cereal Rotations: A Review.” Aust. J. Res. 49: 303-16.

[20] Bado, B. V. 2002. "Role of Legumes on the Tropical Ferruginous Soil Fertility in Guinean and Sudanian Areas of Burkina Faso.” Ph.D. thesis, University of Laval, Department of Soil and Food Engineering, Quebec, Canada, 197. (in French)

[21] Eaglesham, A. R. J., Ayanaba, A., Rao, V. R., and Eskew, D. L. 1982. "Mineral N Effects in Cowpea and Soybean Crops on a Nigerian Soil. Il. Amounts of N Fixed and Added to the Soil.” Plant and Soil 68: 183-92. 


\section{Sorghum Productivity in Burkina Faso}

[22] Zougmoré, R., and Zida, Z. 2000. "Recovering Agricultural Land Encrusted by the Half-Moon Technique.” Data Sheet, INERA. (in French)

[23] MASA/DGESS. 2014. "Yearbook of Agricultural Statistics.” DGESS, 227. (in French)

[24] Yaméogo, J. T. 2012. "Rehabilitation of Forest Ecosystem Degraded in the Sudanian Zone of Burkina Faso: Impacts of CES/DRS Devices.” Ph.D. thesis, Polytechnic University of Bobo-Dioulasso, 160. (in French)

[25] Bonzi, M. 2002. "Assessment and Determinism of the Nitrogen Balance in Cultivated Soil of the Center of Burkina Faso: Study by Isotopic Tracing N15 during Trials in Station and Farm.” Ph.D. thesis, INPL, Nancy, France, 177. (in French)
[26] Ouédraogo, E., Mando, A., and Zombre, N. P. 2001. "Use of Compost to Improve Soil Properties and Crop Productivity under Low Input Agricultural System in West Africa.” Agriculture, Ecosystems \& Environment 84: 259-66.

[27] Ouédraogo, O. 1995. "Contribution to the Study of Some Parasitic Phanerogams of Crops in Burkina Faso: Incidence, Biology and Control Methods.” Ph.D. thesis, University Pierre and Marie Curie, Paris VI, 95. (in French)

[28] Gbèhounou, G., and Toukourou, A. M. 1999. "Impact of Striga hermonthica on Two Varieties of Maize in Pure Cultivation and in Association with the Peanut.” The Agronomic Research Bulletin 25: 9-15. (in French) 